Available online on 15.11.2017 at http://ujpr.org
Universal Journal of Pharmaceutical Research
An International Peer Reviewed Journal
Open access to Pharmaceutical research

\title{
DEVELOPMENT AND EVALUATION OF FAST DISSOLVING THIN FILMS OF ARIPIPRAZOLE

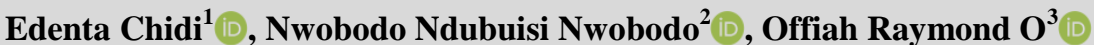 \\ ${ }^{I}$ Department of Biochemistry Renaissance University, Enugu, Nigeria. \\ ${ }^{2}$ Department of Pharmacology and Therapeutics, Division of Clinical Pharmacology and Translational Medicine, Enugu, Nigeria. ${ }^{3}$ Department of Pharmacology and Therapeutics, Faculty of Clinical Medicine, College of Medicine, ESUT, Enugu, Nigeria.
}

\section{ABSTRACT}

Objectives: Aripiprazole, is an atypical antipsychotic. It is recommended and primarily used in the treatment of schizophrenia and bipolar disorder and it undergoes extensive hepatic metabolism. The aim of the current study was to develop thin films of Ariprazole to avoid its hepatic metabolism.

Methods: In the present research, five different rapidly dissolving films of Aripiprazole were prepared successfully by using different polymers by means of solvent casting method. The prepared films were evaluated for different parameters including thickness, mass uniformity, $\mathrm{pH}$, folding endurance, drug content uniformity, cumulative percent release, in-vitro dissolution test and accelerated stability studies. Drug release kinetics of the films, the data obtained were fitted to various kinetic equations

Results: The thicknesses of the films were ranged in between $0.15 \pm 0.14 \mathrm{~mm}$ to $0.20 \pm 0.09 \mathrm{~mm}$ and weight in the range $41.3 \pm 0.68$ to $47.6 \pm 0.83 \mathrm{mg}$. The disintegration time of the films were found to be from $19 \pm 0.48$ to $24 \pm 0.52$ seconds. Formulation of batch F4 has shown maximum release $95.48 \%$ in 30 minutes. There was no significant change in appearance, $\mathrm{pH}$, folding endurance, drug content, in vitro disintegration and percentage drug release during stability testing.

Conclusion: Study concludes effective delivery of Aripiprazole in the form of fast dissolving thin films. On the basis of different evaluated parameters formulation of batch F4 was found to be optimum formulation.

Keywords: Aripiprazole, bioavailability, fast dissolving thin films, first pass metabolism, in-vitro dissolution studies, release kinetics.

Article Info: Received 3 September 2017; Revised 12 October; Accepted 1 November, Available online 15 November 2017

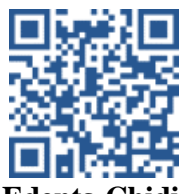
Cite this article-

Chidi E, Nwobodo NN, Offiah RO. Development and evaluation of fast dissolving thin films of aripiprazole. Universal Journal of Pharmaceutical Research 2017; 2(5): 19-23.

DOI: http://doi.org/10.22270/ujpr.v2i5.R5

Address for Correspondence

Edenta Chidi, Department of Biochemistry, Renaissance University, Enugu, Nigeria; E-mail: edentachi1 @gmail.com

\section{INTRODUCTION}

At present scenario there are so many advanced drug delivery system for administration of various drugs through various route, but the oral route is considered as the most convenient and the preferred route of administration because of low-cost and ease of administration increases the patient compliance ${ }^{1}$. More than $70 \%$ of drugs are available in the market in the form of oral drug delivery system. Dysphagia (difficulty in swallowing) is commonly found in pediatric and geriatric patients thus they tend to avoid taking oral solid dosage preparations like tablets and capsules due to fear of choking or suffocation due to physical obstruction ${ }^{2}$. Ultra thin postage stamp size $(2 \times 3 \mathrm{~cm})$ fast dissolving oral thin-film is a novel approach, useful for such types of patients ${ }^{3}$. These films consist of hydrophilic polymers, which rapidly disintegrate or dissolve within a few seconds after coming in contact of saliva to release the drug without need of water or chewing. Since the mucosa is highly enriched with blood supply, it provided quick absorption and instant bioavailability of drugs. It is suitable for the drugs that undergo high first pass metabolism ${ }^{4}$.

Aripiprazole is a phenylpiperazine is effective for the treatment of acute manic episodes of bipolar disorder in adults, children, and adolescents. It is insoluble in water and has a partition co-efficient of $4.537^{5}$. Aripiprazole is an effective add-on treatment for major depressive disorder; however, there is a greater rate of side effects such as weight gain and movement disorders. Aripiprazole displays linear kinetics and has an elimination half-life of approximately 75 hours. Steady-state plasma concentrations are achieved in about 14 days. $\mathrm{C}_{\max }$ (maximum plasma concentration) is achieved 3-5 hours after oral dosing ${ }^{6}$. Bioavailability of the oral tablets is about $90 \%$ and the drug undergoes extensive hepatic metabolism (dehydrogenation, 
hydroxylation, and N-dealkylation), principally by the enzymes CYP2D6 and CYP3A4 ${ }^{7}$. Better patient compliance can be achieved if the drug is given in form of mouth dissolving matrix films. Due to presence of sweet taste and flavors drugs can be delivered just like a mouth freshener rather than a medicine. All these facts make Aripiprazole an ideal candidate to prepare and evaluate as fast dissolving thin films.

\section{MATERIALS AND METHODS}

Aripiprazole was obtained Afrab-Chem Limited, Lagos State, Nigeria. HPMC E-5 LV and Polyvinyl pyrollidone were obtained from Amexco Pharmaceutical Company, Lagos, Nigeria. Propylene glycol and Citric acid were obtained from Emzor Pharmaceuticals Limited, Lagos, Nigeria. Mannitol and menthol were obtained from Food and Pharma Nig. Limited, Lagos, Nigeria.

Development of mouth dissolving film of Aripiprazole by solvent casting method

The casting solution was prepared by mixing polymer solution with drug, sweetener (Mannitol) and flavor (menthol) and saliva stimulating agent (citric acid) as shown in Table 1. All excipients were added with continuous stirring. The resulting solution was deaerated by sonication, then poured into appropriate moulds and dried to obtain the films. The casted films were dried in oven at $60^{\circ} \mathrm{C}$ for three hours or until dryness. The final dosage form was cut into strips $(2 \times 2$ $\mathrm{cm})$ with a stainless steel cutter. The samples were packed in a high density polyethylene sheet, sealed and stored in desiccators at room temperature ${ }^{8}$.

Table 1: Composition of oral thin films containing Aripiprazole.

\begin{tabular}{lcccc}
\hline \multirow{2}{*}{ Ingredients } & \multicolumn{4}{c}{ Code } \\
\cline { 2 - 5 } & F1 & F2 & F3 & F4 \\
\hline Aripiprazole & 120 & 120 & 120 & 120 \\
$\begin{array}{l}\text { HPMC-E5 LV } \\
\text { (mg) }\end{array}$ & 25 & 50 & 75 & 100 \\
$\begin{array}{l}\text { Polyvinyl } \\
\text { pyrollidone }\end{array}$ & 50 & - & 100 & - \\
(mg) & & & & \\
$\begin{array}{l}\text { Citric acid (mg) } \\
\text { Propylene }\end{array}$ & 4 & 4 & 4 & 4 \\
glycol (ml) & 0.25 & 0.2 & 0.25 & 0.2 \\
$\begin{array}{l}\text { Mannitol (mg) } \\
\text { Menthol (mg) }\end{array}$ & 10 & 10 & 10 & 10 \\
$\begin{array}{l}\text { Citric acid (mg) } \\
\text { Purified Water } \\
\text { (ml) }\end{array}$ & 200 & 10 & 10 & 10 \\
\hline
\end{tabular}

\section{Evaluation of films}

\section{Thickness}

Five Aripiprazole films of each formulation were taken and the film thickness was measured by using micrometer screw gauge (Glutfield Nigeria Limited, Nigeria) at different strategic locations (5 locations). Mean thickness and standard deviation were calculated ${ }^{9}$.

\section{Weight variation test}

For weight variation test, 10 Aripiprazole films of every formulation were randomly selected and weighed individually to determine the average weight and standard deviation was also calculated ${ }^{10}$.

Folding endurance

It is expressed as the number of folds required for developing visible cracks or breaking any given film. This gives an indication of brittleness or flexibility of the film. A $2 \times 2 \mathrm{~cm}$ strip was subjected to this test by folding the film at the same point repeatedly several times until a visible crack was observed ${ }^{\mathbf{1 1}}$.

\section{Drug content}

The Aripiprazole films were tested for content uniformity. Films of $2.25 \mathrm{~cm}^{2}$ were cut and placed in a $100 \mathrm{ml}$ volumetric flask and dissolved in methanol and the volume was made up to $100 \mathrm{ml}$. Solution was suitably diluted. The absorbance of the solution was measured at $217 \mathrm{~nm}^{12}$.

\section{Surface $\mathrm{pH}$ of films}

If the $\mathrm{pH}$ of the film is too acidic or alkaline, it may cause irritation. So it is important to determine surface $\mathrm{pH}$ of the film. Surface $\mathrm{pH}$ of the film should be neutral i.e., 7 or should be close to 7 . The Aripiprazole film to be tested was placed in a test tube and was moistened with $1.0 \mathrm{ml}$ of distilled water and kept for 30 second. The $\mathrm{pH}$ was noted by $\mathrm{pH}$ meter (Finlab Nigeria Limited, Nigeria) after bringing the electrode of the $\mathrm{pH}$ meter in contact with the surface of the formulation and allowing equilibrating for $1 \mathrm{~min}$. The average of three determinations for each of the formulation was taken and standard deviation was also calculated ${ }^{13}$.

Percentage moisture loss

For moisture content test, three Aripiprazole films of each formulation were taken. Initially, these selected films were weighed accurately and kept in desiccator containing fused anhydrous calcium chloride ${ }^{14}$. After 3 days, films were removed, weighed and percentage moisture loss was calculated.

\section{Tensile strength}

Tensile strength of the Aripiprazole films was checked by Universal Tensile Strength Testing Machine (LS5, Lloyd Instruments Limited, UK) equipped with a 500 $\mathrm{N}$ load cell. Test was conducted under normal laboratory conditions. The film of $400 \mathrm{~mm}^{2}$ was randomly selected. The lower clamp was held stationary and the film was pulled apart by the upper clamp at a speed of $50 \mathrm{~mm} / \mathrm{min}$. The force of the film at the point, when the film broke was recorded ${ }^{15}$. The experiment was performed in triplicate and average values were reported.

\section{Disintegration time}

This test is carried out using the disintegration apparatus. Three Aripiprazole films from each formulation were taken and performed disintegration test by placing the films in the cylindrical glass tube of disintegration apparatus containing $6.8 \mathrm{pH}$ phosphate buffer. The time at which film disintegrated is noted. Mean and standard deviation were calculated. Normally disintegration time for fast dissolving oral films is $5-30$ seconds ${ }^{16}$.

\section{In vitro dissolution test}

The dissolution test on Aripiprazole films was performed using the USP apparatus II (Finlab, Nigeria, Limited, Nigeria). The dissolution test was performed using the $500 \mathrm{ml}$ of simulated saliva solution, which 
consist of $\mathrm{pH} 6.8$ phosphate buffer as dissolution medium. The temperature of the medium was maintained at $37 \pm 0.5^{\circ} \mathrm{C}$. The apparatus was set at 50 rpm. A film sample of $4 \mathrm{~cm}^{2}(2 \times 2 \mathrm{~cm})$ was cut and placed in the basket. Five $\mathrm{ml}$ of samples were withdrawn at an interval of 2 minutes for 16 minutes and the same amount of the dissolution medium was replaced with fresh phosphate buffer at the same time in order to maintain the sink condition throughout the dissolution medium. The withdrawn samples were filtered using Whatman filter paper. Appropriate dilutions were made to the withdrawn sample and were analyzed through UV spectrophotometer at a wavelength of $217 \mathrm{~nm}$. The dissolution study was performed in triplicates and the average value of percentage release was taken ${ }^{17}$.

\section{Accelerated stability studies}

The stability studies on Aripiprazole films were conducted according to ICH guidelines to investigate the effect of temperature, relative humidity on drug in formulation. Final optimized formulation of batch F4 was subjected to aggravated conditions of temperature and relative humidity by wrapping it in aluminum foil and packaging it in glass container. The films were kept in stability chamber, at $40 \pm 2^{\circ} \mathrm{C}$ temperature and $75 \pm 5 \% \mathrm{RH}$ for 45 days. After it, films were tested for thickness, weight variation, folding endurance, disintegration time, $\%$ drug content, and in-vitro drug release ${ }^{18}$.

Table 2: Evaluation of physicochemical parameters of Aripiprazole films.

\begin{tabular}{ccccccccc} 
Code & $\begin{array}{c}\text { Thickness } \\
(\mathbf{m m})\end{array}$ & $\begin{array}{c}\text { Weight } \\
\text { uniformity } \\
(\mathbf{m g})\end{array}$ & $\begin{array}{c}\text { Surface } \\
\mathbf{p H}\end{array}$ & $\begin{array}{c}\text { \% Drug } \\
\text { content }\end{array}$ & $\begin{array}{c}\text { Moisture } \\
\text { content loss } \\
(\boldsymbol{\%})\end{array}$ & $\begin{array}{c}\text { Folding } \\
\text { endurance }\end{array}$ & $\begin{array}{c}\text { Tensile } \\
\text { strength } \\
(\mathbf{m P a})\end{array}$ & $\begin{array}{c}\text { Disintegration } \\
\text { time (Sec.) }\end{array}$ \\
\hline F1 & $0.15 \pm 0.14$ & $41.3 \pm 0.68$ & $6.38 \pm 0.02$ & $96.6 \pm 0.28$ & $8.41 \pm 0.29$ & $183 \pm 1.02$ & $3.67 \pm 0.08$ & $19 \pm 0.48$ \\
F2 & $0.17 \pm 0.23$ & $43.2 \pm 0.57$ & $6.43 \pm 0.03$ & $96.51 \pm 0.03$ & $7.52 \pm 0.25$ & $187 \pm 1.45$ & $2.84 \pm 0.09$ & $21 \pm 0.49$ \\
F3 & $0.19 \pm 0.13$ & $45.5 \pm 0.16$ & $6.74 \pm 0.04$ & $98.48 \pm 0.48$ & $6.82 \pm 0.25$ & $226 \pm 2.03$ & $3.83 \pm 0.11$ & $22 \pm 0.51$ \\
F4 & $0.20 \pm 0.09$ & $47.6 \pm 0.83$ & $6.52 \pm 0.03$ & $99.89 \pm 0.82$ & $5.63 \pm 0.73$ & $232 \pm 1.94$ & $4.23 \pm 0.06$ & $24 \pm 0.52$ \\
\hline
\end{tabular}

Table 3: Statistical analysis of Aripiprazole films.

\begin{tabular}{cccccccccccc}
\hline Code & \multicolumn{2}{c}{ Zero order } & \multicolumn{2}{c}{ First order } & \multicolumn{2}{c}{ Higuchi Plot } & \multicolumn{2}{c}{ Hixon-Crowell } & \multicolumn{3}{c}{ Korsmeyer-Peppas } \\
\cline { 2 - 12 } & $\mathbf{K}_{\mathbf{0}}$ & $\mathbf{R}^{\mathbf{2}}$ & $\mathbf{K}_{\mathbf{1}}$ & $\mathbf{R}^{\mathbf{2}}$ & $\mathbf{K}_{\mathbf{H}}$ & $\mathbf{R}^{\mathbf{2}}$ & $\mathbf{K}_{\mathbf{H C}}$ & $\mathbf{R}^{\mathbf{2}}$ & $\mathbf{K}_{\mathbf{K P}}$ & $\mathbf{R}^{\mathbf{2}}$ & $\mathbf{N}$ \\
\hline F1 & 5.6328 & 0.9765 & 0.1754 & 0.8963 & 24.321 & 0.9331 & 0.1883 & 0.8917 & 1.9471 & 0.8854 & 0.2361 \\
F2 & 6.7891 & 0.9647 & 0.1867 & 0.9158 & 25.413 & 0.9473 & 0.1741 & 0.8764 & 2.4628 & 0.8637 & 0.3114 \\
F3 & 7.0215 & 0.8971 & 0.1843 & 0.8951 & 23.541 & 0.9234 & 0.2265 & 0.9331 & 1.8243 & 0.9146 & 0.2941 \\
F4 & 6.9874 & 0.8558 & 0.2043 & 0.8862 & 25.338 & 0.9148 & 0.2345 & 0.9486 & 2.3781 & 0.8965 & 0.3252 \\
\hline
\end{tabular}

\section{RESULTS AND DISCUSSION}

In the present study, fast dissolving oral thin films of Aripiprazole were prepared successfully by using different polymer such as hydroxypropyl methyl cellulose (HPMC-E5 LV), polyvinyl pyrollidone using solvent casting method. Total five formulations were prepared. Formulations were totally homogenous, flexible with smooth surface both sides. The films were evaluated for various properties including thickness, mass uniformity, $\mathrm{pH}$, folding endurance, drug content uniformity, cumulative percent release, in-vitro dissolution test and accelerated stability studies. It was found that as the concentration of the polymer increases the flexibility of the film decreases. Films with very low concentration of polymer were sticky and brittle in nature. The films with optimum concentration of polymer were found to have good, flexible film forming property. The thicknesses of the films were found to be from $0.15 \pm 0.14 \mathrm{~mm}$ to $0.20 \pm 0.09 \mathrm{~mm}$. The thicknesses of the films were found to increase with increase in concentration of the polymer. The weight variations of the samples were found to be in the range $41.3 \pm 0.68$ to $47.6 \pm 0.83 \mathrm{mg}$. It was observed that slight increase in the weight of films was due to increase in concentration of the polymer.

The folding endurance of the film was found to be in the range $183 \pm 1.02$ to $232 \pm 1.94$. The folding endurance was found to increases with increase in concentration of the polymer. The tensile strength of

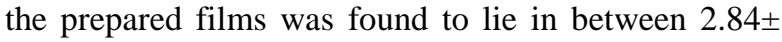

0.09 to $4.23 \pm 0.06 \mathrm{Kg} / \mathrm{mm}^{2}$.Tensile strength was found to increase with increase in concentration of polymer. The $\mathrm{pH}$ of the films was found to be in the range between $6.38 \pm 0.02$ to $6.74 \pm 0.04$.

Table 4: Stability study of Aripiprazole films of batch F4.

\begin{tabular}{lcc}
\hline Parameter & Initial & $\begin{array}{c}\text { After 45 days } \\
\mathbf{a t} \mathbf{4 0} \mathbf{C}, \mathbf{7 5 \%} \\
\mathbf{R H}\end{array}$ \\
\hline Thickness & $0.20 \pm 0.09$ & $0.17 \pm 006$ \\
Weight variation & $47.6 \pm 0.83$ & $47.1 \pm 0.25$ \\
$\begin{array}{l}\text { Folding } \\
\text { endurance }\end{array}$ & $232 \pm 1.94$ & $229 \pm 0.58$ \\
$\begin{array}{l}\text { Disintegration } \\
\text { Time }\end{array}$ & $24 \pm 0.52$ & $22 \pm 0.64$ \\
\% Drug content & $99.89 \pm 0.82$ & $98.86 \pm 0.08$ \\
$\begin{array}{l}\text { Surface pH } \\
\text { In-vitro drug }\end{array}$ & $6.52 \pm 0.03$ & $6.32 \pm 0.11$ \\
release & $95.48 \%$ in & $95.37 \%$ in 30 \\
\hline & $30 \mathrm{~min}$ & $\mathrm{~min}$ \\
\hline
\end{tabular}

Drug content of the films with all polymers was found to be in the range of $96.51 \pm 0.03$ to $99.89 \pm 0.82 \%$. Estimation of drug content indicated that the drug is uniformly distributed throughout the film for most of the films evidenced by the low values of standard deviation. The disintegration time of the films were found to be from $19 \pm 0.48$ to $24 \pm 0.52$ seconds. It was observed that disintegration time of a film increases with increase in concentration of the polymer. It was observed that the drug release was found to decrease with increase in concentration of polymer. It 
indicates that increase in level of polymer, results in formation of high viscous gel layer caused by more intimate contact between the particles of polymers resulting in decreased mobility of drug particles in swollen matrices, finally leading to decreased release rate. Formulation of batch $\mathrm{F} 4$ has shown maximum release $95.48 \%$ in 30 minutes. For analyzing the mechanism of drug release kinetics of the films, the data obtained were fitted to various kinetic equations of zero order, first order, Higuchi model and KorsmeyerPeppas model. The regression coefficient was calculated. Regression coefficients are summarized in Table 4. The optimized formulation F4 was evaluated for the stability studies. Formulations were stored at $40^{\circ} \mathrm{C}, 75 \% \mathrm{RH}$ for 45 days. From the evaluation, it was found that there is no significant change in appearance, $\mathrm{pH}$, folding endurance, drug content, in vitro disintegration and percentage drug release.

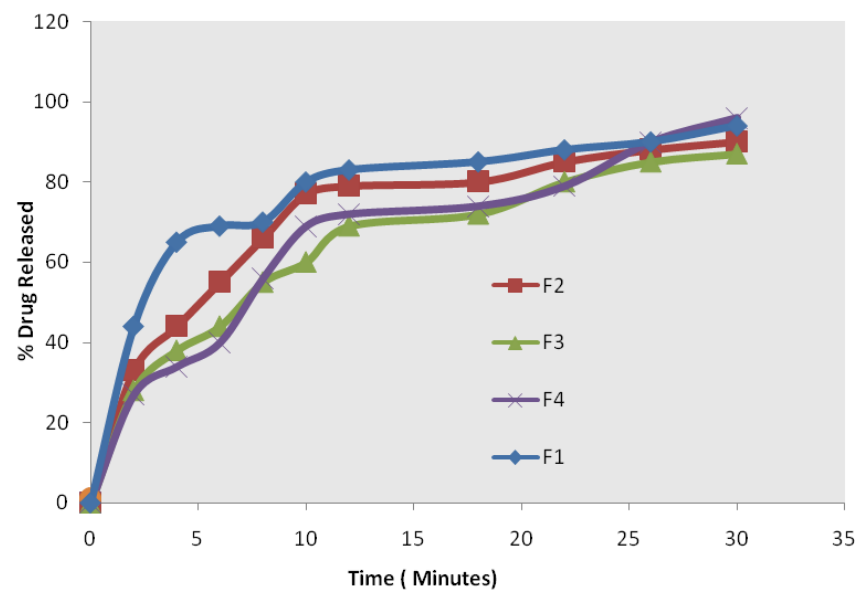

Figure 1: In-vitro dissolution profile of Aripiprazole films.

\section{CONCLUSION}

Fast dissolving oral thin films for oral cavity are an innovative and promising dosage form especially for use in pediatrics and geriatrics or others have difficulty of swallowing. The results have shown that the HPMCE5 LV is a good film former. In combination with PG, it has shown promising fast drug release within $30 \mathrm{~min}$. Successful formulation of Aripiprazole mouth dissolving films may prevent first pass metabolism to a large possible extent. However to verify this fact there is need of in-vivo study using Aripiprazole films. On the basis of different evaluated parameters formulation of batch F4 was found to be optimum formulation. The preparation of films did not require the addition of any disintegrant separately, so this formulation seems to be an attractive alternative to conventional marketed formulations. Present study concludes that mouth dissolving films is a potential drug delivery system for Aripiprazole with a considerably good physicochemical characteristics and release profile.

\section{AUTHOR'S CONTRIBUTION}

The manuscript was carried out, written, and approved in collaboration with all authors.

\section{ACKNOWLEDGEMENTS}

The authors extend their thanks and appreciation to the Renaissance University, Enugu, Nigeria to provide necessary facilities for this work.

\section{CONFLICT OF INTERESTS}

There are no conflicts of interest.

\section{REFERENCES}

1. Nishimura M, Matsuura K, Tsukioka T, Yamashita H, Inagaki $\mathrm{N}$, Sugiyama $\mathrm{T}$, Itoh $\mathrm{Y}$. In vitro and in vivo characteristics of prochlorperazine oral disintegrating film. Int J Pharmaceutics 2009; 368(1-2): 98-102. https://doi.org/10.1016/j.ijpharm.2008.10.002

2. Rawda KA, Shabarayal AR, Azharuddin M. Design and evaluation of fast dissolving oral films of granisetron hydrochloride. Am J Pharm Tech Res 2012; 2(6): 591609. https://doi.org/10.13140/RG.2.2.11262.23360

3. Gade R, Aynampudi A, Makineni A, Murthy TEGK, Rao $\mathrm{CB}$, Nama S. Design and development of pravastatin sodium fast dissolving films from natural mucilage of Ocimum bacilicum seeds. Int J Pharmaceut Res Rev 2014; 2(3): 17-27.

4. Kaza R, Prasanna RY, Ravouru N. Design and characterization of fast dissolving films of valsartan. Turk J Pharm Sci 2014; 11(2): 175-184. https://doi.org/10.1007/s00289-018-2503-y

5. Leucht S, Cipriani A, Spineli L, Mavridis D, Orey D, Richter F, Samara M, Barbui C, Engel RR, Geddes JR, Kissling W, Stapf MP, Lässig B, Salanti G, Davis JM (September 2013). Comparative efficacy and tolerability of 15 antipsychotic drugs in schizophrenia: a multipletreatments meta-analysis. Lancet 382 (9896): 951-62. https://doi.org/10.1016/S0140-6736(13)60733-3

6. Barnes TR. Evidence-based guidelines for the pharmacological treatment of schizophrenia: recommendations from the British Association for Psychopharmacology. J Psychopharmacol 2011; 25 (5): 567-620. https://doi.org/10.1177/0269881119889296

7. De Fruyt J, Deschepper E, Audenaert K, Constant E, Floris M, Pitchot W, Sienaert P, Souery D, Claes S. Second generation antipsychotics in the treatment of bipolar depression: a systematic review and meta-analysis. J Psychopharmacol 2012; 26 (5): 603-17.

8. Kai BL, Yvonne Tze Fung Tan, Kok K Khiang Peh. Characterization of oral disintegrating film containing donepazil for the alzhemier disease. AAPS Pharm Sci Tech 2012; 13:134-42. https://doi.org/10.1208/s12249011-9729-4

9. Dinge A, Nagarsenker M. Formulation and evaluation of fast dissolving films for delivery of triclosan to the oral cavity. AAPS Pharm Sci Tech 2008; 9(2): 349-56. https://doi.org/10.1208/s12249-008-9047-7 
10. Chen MJ, Tirol G, Bass C, Corniello CM, Watson G, Sanchez I. Castable edible pharmaceutical films. Drug Del Tech 2008; 8(6): 35-41.

11. Francesco C, Irma EC, Paola M, Susanna B, Francesca S, Chiara GMG, Luisa M. Nicotine fast dissolving films made of maltodextrins: A feasibility study. American Assoc Pharm Sci Pharm Sci Tech 2010; 11 (4), 15111517. https://doi.org/10.1208/s12249-010-9525-6

12. Yasmeen R, Firoz, Y, Chandra Mouli, Vikram A, Mahitha B. Preparation and evaluation of oral fast dissolving films of citalopram hydrobromide. Int J Bioph 2012; 2, 103106.

13. Barnhart S D, Sloboda M S, The future of dissolvable films, Drug Deliv Technol 2007; 7: 34-37.

14. Juluru NS. Fast dissolving oral films: a review. Int J Advan Pharm Bio Chem 2013; 2(1): 108-112.
15. Sayed HA, Mahmoud ELB, Mohamed AI. Design, formulation and characterization of fast dissolving films containing dextromethorphan. Dig J Nanomater Biostruct 2014; 9: 133-141.

16. Marzia A, Tasneem F, Pathan SI. Formulation and evaluation of swellable oral thin film of metoclopramide hydrochloride. Bangladesh Pharmaceutical J 2014; 17(1): 102-112.https://doi.org/10.3329/bpj.v17i1.22325

17. Yoshifumi M, Takashi I, Kofuji K, Nishida N, Kamaguchi R. Preparation of fast dissolving films for oral dosage from natural polysaccharides. Materials 2010; 3: 4291-4299.https://doi.org/10.3390/ma3084291

18. El-Nabarawi MA, Makky AM, ElSetouhy DA, Abd Elmonem RA, Jasti BA. Development and characterization of ketorolac tromethamine (Kt) orobuccal films. Int J Pharm Pharm Sci 2012; 4(4): 186193. 